\title{
Decreased Sperm Motility is Associated with Increased Seminal Plasma IGF-I, IGF-II, IGFBP-2 and PSA Levels in Male Infertility
}

\section{Li Fu}

National University of Singapore - Kent Ridge Campus: National University of Singapore

Kevin Yuen ( $\square$ kevin.yuen@dignityhealth.org )

Barrow Neurological Institute https://orcid.org/0000-0002-8169-2728

Aye Nyein Tint

National University of Singapore - Kent Ridge Campus: National University of Singapore

Andrew R. Hoffman

VA Palo Alto Health Care System Palo Alto Division: VA Palo Alto Health Care System

Ariff T. Bongso

National University of Singapore

Kok Onn Lee

National University of Singapore - Kent Ridge Campus: National University of Singapore

\section{Research Article}

Keywords: Insulin-like growth factors, insulin-like growth factor binding proteins, prostate-specific antigen, male infertility, seminal plasma, sperm, aging

Posted Date: May 12th, 2021

DOl: https://doi.org/10.21203/rs.3.rs-504119/v1

License: (c) (i) This work is licensed under a Creative Commons Attribution 4.0 International License. Read Full License

Version of Record: A version of this preprint was published at Endocrine on July 17th, 2021. See the published version at https://doi.org/10.1007/s12020-021-02823-w. 


\section{Abstract}

\section{Purpose}

Previous studies have suggested the involvement of serum IGFs and IGFBPs in the regulation of the female reproductive system. Little is known of these peptides in the seminal plasma (SP) of men and their potential effects on fertility. We assessed SP levels of these peptides in infertile men with low sperm motility (asthenozoospermic; AZ) and low sperm counts (oligozoospermic; $\mathrm{OZ}$ ), its effects on in vivo sperm motility, and whether aging affects these peptides.

\section{Methods}

Twenty eight infertile men ( $A Z ; n=18$ and $O Z ; n=10)$ and 20 fertile normozoospermic (NZ) men were studied. Seminal plasma IGF-I, IGF-II, IGFBP-2, IGFBP-3 and PSA levels were measured, and spermatozoa mRNA transcript patterns were examined.

\section{Results}

Asthenozoospermic men had higher SP IGF-I, IGF-II, IGFBP-2 and PSA levels than NZ and OZ men (all $P<$ 0.05), whereas SP IGFBP-3 levels were no different between the three groups. Sperm count positively correlated with SP IGF-I, IGF-II and IGFBP-2; sperm motility negatively correlated with SP IGF-II and IGFBP2; and age correlated positively with SP IGF-II (all $P<0.04$ ). The expression of IGF-I and IGF-II mRNA and mRNA receptors was detectable, but no variations in transcript levels were noted.

\section{Conclusion}

Decreased sperm motility, but not sperm count, in infertile AZ men is associated with increased SP IGF-I, IGF-II, IGFBP-2 and PSA levels. Changes in SP IGFs and their interactions with IGFBPs and IGF receptors, and PSA levels suggest a role of these SP peptides in modulating sperm motility and possibly prostate disease development in aging men.

\section{Introduction}

Increasing evidence has implicated the role of the GH/IGF system in human reproductive physiology [1, 2]. Growth hormone modulates gonadotropin secretion and regulates longitudinal growth and function of secondary sexual organs, including activation of the formation of uterus in females and prostate and seminal vesicles in males [2]. Exogenous GH administration has been suggested as a potential treatment option for male infertility by increasing sperm count and total motile spermatozoa in infertile idiopathic oligozoospermic (OZ) men [3], improving sperm motility in asthenozoospermic (AZ) and OZ men [4, 5], and might even induce pregnancies in AZ men [6]. Although GH promotes the secretion of IGF-I and IGF-II mainly from the liver [7], localized testicular and prostatic production of these peptides are independent of $\mathrm{GH}$ induction [8] and can act in an autocrine/paracrine fashion [9]. Furthermore, circulating IGFs are bound by specific binding proteins (IGFBPs) that modulate their activity [10]. Production of IGFBPs is 
ubiquitous and different IGFBPs are found in various body fluids. In serum, IGFBP-3 is predominant, whereas in seminal plasma (SP) and cerebrospinal fluid, IGFBP-2 is the most abundant binding protein $[11,12]$.

In the female reproductive system, studies have demonstrated the presence of IGFs and IGFBPs in granulosa cell cultures, follicular fluid, endometrium, and amniotic fluid, suggesting their involvement in the regulation of germ cell maturation, endometrial proliferation, and placental growth [13]. Conversely, the role of IGFs and IGFBPs in the male reproductive system has been less well studied. Although the presence of IGFs and IGFBPs have been demonstrated in SP [14-20], it remains unclear what these levels are in infertile men with low sperm motility versus those with low sperm counts, and if they exert a specific functional role in affecting sperm characteristics.

Previous studies have suggested that higher serum IGF-I levels is associated with a higher risk of benign prostatic hypertrophy (BPH) [21] and prostate cancer [22, 23]. Paradoxically, as men age, serum IGF-I levels decline [24] whereas the incidence of prostate diseases increases [25, 26]. We have previously shown that IGFBP-3 is present in SP and was completely proteolyzed into smaller molecular weight fragments by specific proteases [27], one of which was prostate-specific antigen (PSA), thus increasing bioavailable SP IGFs. It is, thus, possible that prostatic rather than serum IGFs may be more important in contributing to the pathogenesis of prostate diseases in aging men.

Therefore, to gain a better understanding of whether SP changes of IGFs, IGFBPs and PSA levels occurred in specific types of male infertility, we measured SP IGF, IGFBP and PSA profiles in fertile normozoospermic (NZ) men with normal sperm parameters, and infertile OZ men with low sperm counts and AZ men with low sperm motility. Additionally, we examined mRNA transcript patterns in mature motile spermatozoa to determine if there was a direct functional effect of SP IGFs and IGFBPs on in vivo sperm motility, and investigated if there are any age-related changes in SP IGF and IGFBP levels.

\section{Subjects And Methods}

\section{Subjects}

Twenty eight infertile men with abnormal semen analyses who attended the National University Hospital of Singapore Infertility Clinic were studied. All men were otherwise healthy on physical examination that included testicular examinations, non-smokers, not on any medications, and did not have any documented genitourinary tract infection at the time on enrolment. The infertile men were categorized into two groups based on their semen parameters, as classified by the World Health Organization (WHO) 2010 criteria [28]. The AZ men is classified as having normal sperm counts $\left(>20 \times 10^{6} / \mathrm{mL}\right)$ with low sperm motility ( $<50 \%$ motile sperm), and the $\mathrm{OZ}$ men is classified as having low sperm counts $(<20$ million ${ }^{6} / \mathrm{mL}$ ) with normal sperm motility (> 50\% motile sperm). Twenty fertile NZ men, defined as having normal sperm counts ( $>20 \times 10^{6} / \mathrm{mL}$ ) and normal sperm motility (>50\% motile sperm) based on the WHO 2010 criteria [28], were also recruited that served as control subjects. These men were healthy male 
volunteers whose wives/partners had produced an offspring within the previous 2 years, and were not on any medications. This study was approved by the National University Hospital of Singapore Institutional Review Board and informed consent was obtained from all subjects.

\section{Seminal plasma collection and sperm extraction}

Seminal plasma samples were collected from the semen of all subjects by masturbation after at least 48 hours of sexual abstinence into sterile specimen cups and placed in a $37^{\circ} \mathrm{C}$ heat block for 2 hours. After liquefaction, samples were centrifuged at room temperature for 7 minutes at $450 \mathrm{xg}$. Supernatants were re-centrifuged and the final supernatants filtered through $0.2 \mu$ millipore filters and then frozen at $-70^{\circ} \mathrm{C}$. Viscous semen that could not be liquefied and semen with leucocytospermia were excluded, and these subjects were invited to return to the Infertility Clinic at another date for a repeat semen collection.

After the semen sample was liquefied at room temperature, the semen was examined for sperm motility characteristics using a mackler chamber and a phase contrast microscope. About 0.5-1.0 mL of semen was stored from each sample for total RNA extraction. After collection, the semen samples were placed into small $2 \mathrm{~mL}$ tubes and mixed with 1 to 2 volumes of Phosphate Buffered Solution. These were spun in a microcentrifuge at $13000 \mathrm{rpm}$ for 2 minutes, and this process of washing the spermatozoa was repeated on 2 occasions. Sperm counts $\left(x 10^{6} / \mathrm{mL}\right)$ and sperm motility (\%) were assessed according to the WHO 2010 criteria [28] by a trained observer and sperm motility was assessed using the patient's own SP as media. The supernatant was then discarded and the pellet containing washed spermatozoa were subjected to RNA extraction.

\section{Measurement of SP IGFs, IGFBPs and PSA levels}

Seminal plasma IGF-I and IGF-II levels were measured by an immunoradiometric assay (IRMA) using commercially available kits (Diagnostic System Laboratories, Webster, Texas, USA), as previously described (Lee). For the measurement of SP IGFs, there was no interference from IGFBP-2 and IGFBP-3 as all these binding proteins were all washed out, as previously described [29]. Seminal plasma IGFBP-2 and IGFBP-3 was measured by a radioimmunoassay (RIA) kit (Diagnostic System Laboratories, Webster, Texas, USA). For the measurement of SP IGFBP-3, the RIA kit was previously validated [27] to measure low molecular weight fragments. Seminal plasma PSA levels were measured using an enzyme-linked immunosorbent assay, performed by using a commercially available PSA kit (Diagnostic System Laboratories, Webster, Texas, USA) according to manufacturer instructions.

\section{Extraction of RNA}

Total RNA was isolated from the spermatozoa using the RNAeasy mini kit (Qiagen, Germany) according to manufacturer's instructions and re-suspended in RNase-free water. Quantification and purity of the RNA was assessed by A260/A280 absorption and RNA quality was assessed by agarose gel electrophoresis. RNA samples with ratios $>1.6$ were stored at $-70^{\circ} \mathrm{C}$ for further analysis. 
Reverse transcription (RT)

First-strand cDNA synthesis was carried out using Omniscript reverse transcriptase (Qiagen, Germany). Total RNA of $1-2 \mu \mathrm{g}$ was incubated for $60 \mathrm{~min}$ at $37^{\circ} \mathrm{C}$ in a $20 \mu \mathrm{L}$ reaction volume. The reaction was stopped by incubating at $93^{\circ} \mathrm{C}$ for 5 minutes and then quick-chilled on ice.

\section{Polymerase chain reaction (PCR)}

Polymerase chain reaction was performed in a final reaction volume of $50 \mu \mathrm{L}$ containing the following reagents by use of the Taq PCR Core Kit (Qiagen, Germany): PCR buffer, Q-solution, dNTP mix, primer A, and taq DNA polymerase. The sequence of oligonucleotide primers are displayed in Table 1. Samples were heated to $94^{\circ} \mathrm{C}$ for 3 minutes and the denatured cDNA templates were amplified by the following cycles: $94^{\circ} \mathrm{C}$ for 1 minute (denature); $55^{\circ} \mathrm{C}$ (annealing temperature for IGF-I, IGF-II, IGF-I receptor, IGF-II receptor) for 1 minute; and then extended for 1 minute at $72^{\circ} \mathrm{C}$. After 35 cycles, a final extension was performed for 10 minutes at $72^{\circ} \mathrm{C}$, then cooled rapidly and stored at $4^{\circ} \mathrm{C}$. Following amplification, $10 \mu \mathrm{L}$ of the reaction products mixed with $2 \mu \mathrm{L}$ of Blue/orange $6 \mathrm{X}$ loading dye (Promega, USA) was applied to a $1.5 \%$ agarose (GIBCO BRL, NY, USA) gel containing a minimal amount of ethidium bromide. Molecular weight standards included $5 \mu \mathrm{g}$ of ' 100 bp DNA Ladder ${ }^{\circledR}$ ' (New England Biolabs Inc., USA). At the end of electrophoresis, the intensity of RT-PCR products was visualized on an ultraviolet box.

\section{Statistical analysis}

All statistical analyses were performed using SPSS for Windows (version 15.0, SPSS, Chicago, IL). To test for significant differences between the SP IGF-I, IGF-II, IGFBP-2, IGFBP-3 and PSA levels of the 3 subject groups, comparisons between groups were assessed using the one-way analysis of variance (ANOVA) with Dunnett's post hoc test. Correlation coefficients were calculated using Pearson's correlation for parametric data (sperm count, IGFs, IGFBP-3, PSA and age) and Spearman's correlation for nonparametric data (sperm motility). A two-tailed $P$-value of $<0.05$ defined statistical significance.

\section{Results}

\section{Baseline patient characteristics (Table 2)}

The patients in the 3 groups (age range 22 to 57 years) were well-matched with no differences with regard to age and body mass index. The AZ men had a lower percentage of motile sperm $(28.4 \pm 2.5 \%)$ than the NZ $(58.8 \pm 1.3 \%)$ and $\mathrm{OZ}(57.6 \pm 3.1 \%)$ men, whereas the $\mathrm{OZ}$ men had lower sperm counts $(7.5 \pm$ $\left.1.8 \times 10^{6} / \mathrm{mL}\right)$ than the NZ $\left(45.0 \pm 4.9 \times 10^{6} / \mathrm{mL}\right)$ and $\mathrm{AZ}\left(57.9 \pm 8.7 \times 10^{6} / \mathrm{mL}\right)$ men (all $P<0.0001$, ANOVA).

\section{Seminal plasma IGF-I, IGF-II, IGFBPs and PSA levels (Figure 1)}

Seminal plasma IGF-I levels were higher in the AZ $(90.0 \pm 13.5 \mathrm{ng} / \mathrm{mL})$ compared to the NZ $(62.6 \pm 12.0$ $\mathrm{ng} / \mathrm{mL})$ and $\mathrm{OZ}(45.6 \pm 10.5 \mathrm{ng} / \mathrm{mL})$ men $(P<0.05$, ANOVA). Similarly, SP IGF-II levels were also higher in 
the AZ $(1441 \pm 64 \mathrm{ng} / \mathrm{mL})$ compared to the NZ $(1130 \pm 79 \mathrm{ng} / \mathrm{mL})$ and $O Z(1011 \pm 129 \mathrm{ng} / \mathrm{mL})$ men $(P<$ 0.05 , ANOVA). Seminal plasma IGFBP-2 levels were higher in the AZ $(7391 \pm 665 \mathrm{ng} / \mathrm{mL}) \mathrm{compared}$ to the $\mathrm{NZ}(5870 \pm 549 \mathrm{ng} / \mathrm{mL})$ and $\mathrm{OZ}(5010 \pm 354 \mathrm{ng} / \mathrm{mL})$ men $(P<0.05$, ANOVA $)$. In contrast, SP IGFBP-3 levels did not differ between the 3 subject groups. Seminal plasma PSA levels were higher in the AZ $(2.2 \pm$ $0.2 \mathrm{mg} / \mathrm{ml})$ compared to the NZ $(1.4 \pm 0.1 \mathrm{mg} / \mathrm{ml})$ and OZ $(1.2 \pm 0.2 \mathrm{mg} / \mathrm{ml}) \mathrm{men}(P<0.05$, ANOVA $)$.

\section{Expression of IGF-I and IGF-II mRNA and receptor mRNA in mature motile spermatozoa (Figure 2)}

The expression of IGF-I and IGF-II mRNA and IGF-I and IGF-II receptor mRNA in mature motile spermatozoa was detectable by RT-PCR. Using total RNA isolated from mature motile spermatozoa, low amounts of amplified cDNAs were detected using the IGF-I specific primers and abundant amplification of cDNA was observed with IGF-II specific primers. Specific primers for IGF-I and IGF-II receptors amplified cDNA from RNA were isolated from mature motile spermatozoa. No differences were observed in the transcript levels of IGF-I and IGF-II mRNA and mRNA receptors in the 4 spermatozoa samples tested.

\section{Correlation analyses (Table 3)}

Sperm count positively correlated with SP IGF-I, IGF-II and IGFBP-2 and sperm motility negatively correlated with SP IGF-II and IGFBP-2. Aging positively correlated with SP IGF-II, IGFBP-2 and PSA.

\section{Discussion}

In the present study, we found that AZ men with low sperm motility had significantly higher SP IGF-I, IGFII, IGFBP-2 and PSA levels than NZ and OZ men implying that increased SP levels of these peptides was associated with decreased sperm motility, but not decreased sperm count. Conversely, SP IGFBP-3 levels (consisting mainly of low molecular weight IGFBP-3 fragments) were similar across the three groups suggesting that this peptide does not contribute to any meaningful effect in the pathogenesis of male infertility. The presence of IGF-I, IGF-II, and IGF-I and IGF-II receptors in mature motile spermatozoa suggests a direct role of these peptides in modulating in vivo sperm motility, and SP IGF-II, IGFBP-2 and PSA, but not SP IGF-I, levels increase with aging suggesting that SP IGF-II may be an implicating factor in the development of $\mathrm{BPH}$ and prostate cancer as men age.

Previous studies have investigated the role of IGF-I in sperm function, semen quality, and infertility in terms of a mitogenic, metabolic, and differentiating polypeptide with endocrine, paracrine, and autocrine effects $[8,30]$. Animal studies have demonstrated that the proportion of normal spermatozoa was related to serum IGF-I levels in bulls [31]. Additionally, bovine SP IGF-I levels were related to semen quality [32] and motility in buffalos [33] and rams [34], and exogenous IGF-I administration improved sperm parameters in buffalo bulls [35]. Seminal plasma, the non-cellular component of semen, is a heterogeneous composite fluid built by secretions of the testis, the epididymis and the accessory sexual glands that is relevant for fertility [36]. Early human studies have shown the presence of IGF-I, IGF-II, IGFBP-2, IGFBP-3 fragments, IGFBP-4, IGFBP-5, IGFBP- protease activities and PSA in SP $[14,18,19,27$, 37-39], while recent studies have reported that SP IGF-I levels do not differ between men with normal and 
abnormal semen parameters $[15,20]$. Evidence that vasectomized patients had lower SP IGF-I levels than intact patients suggests that SP IGF-I is mainly of testicular origin [39], whereas in patients with varicocele (a common cause of male infertility), higher SP IGF-I levels than healthy fertile men have been observed implying a role of localized IGF-I in the pathogenesis of male infertility [17].

We and others $[30,40]$ have shown that spermatozoa contains IGF-I receptors, so it is possible that the increased SP IGF-I levels can directly modulate sperm motility through these receptors. Although our data are in line with some studies where higher SP IGF-I levels are associated with abnormal sperm parameters [14, 17], others have reported either improved sperm parameters with increased SP IGF-I levels $[9,30,33,41]$ or unchanged SP IGF-I levels with abnormal sperm parameters $[15,20]$. These discordant results suggest that there might be other local factors (e.g., IGF-II, IGFBPs and IGFBP proteolytic activity) that can influence the bioavailability and bioactivity of SP IGF-I.

To our knowledge, the present study is the first to investigate whether SP IGF-II might have any relationship with sperm function. The levels of IGF-II observed in the SP of fertile NZ men $(1130 \pm 79$ $\mathrm{ng} / \mathrm{mL}$ ) are comparable with those reported by Ramasharma et al. [18] (1575 $\pm 66 \mathrm{ng} / \mathrm{mL})$, and are notably 15-20 fold higher than the SP IGF-I levels. Our results concerning SP from AZ men with low sperm motility and increased IGF-II levels suggest that IGF-II, together with IGF-I, may act synergistically to inhibit sperm motility. Our findings are consistent with those reported by Henricks et al. [40] in which exogenous IGF-I and IGF-II increased the motility of washed bovine spermatozoa in an in vitro system devoid of IGFBPs. However, the in vitro system used in this study does not fully represent the in vivo environment because substantial amounts of IGFBPs are present in bovine SP that may modify the half-life and receptor interactions of IGFs.

Our study demonstrated that SP IGFBP-2 levels were significantly higher in AZ compared to NZ and OZ men. In normal men, there were no differences in SP IGFBP-2 levels before and after vasectomy, implying decreased IGFBP-2 secretion occurs in the testis rather than in the accessory sex glands [39]. This is consistent with the findings by Cohen et al. [42] who reported that IGFBP-2 was found in prostate epithelial cell-conditioned medium. Studies from both in vivo and in vitro models suggest that IGFBP-2 exerts inhibitory effects on IGF-mediated functions [43]. Hence, it is likely that SP IGFBP-2 may not induce any meaningful inhibitory effects on IGF-I and IGF-II actions in affecting sperm motility. Our data also indicated that SP IGFBP-3 levels were similar across the three groups. We have previously shown that SP IGFBP-3 is proteolyzed into low molecular weight fragments by PSA and other local proteases, resulting in a loss of intact IGFBP-3 [27]. These low molecular weight IGFBP-3 fragments do not to bind to IGF-I or IGF-II, and were comparable between normal and vasectomized males, and patients with idiopathic azoospermia, suggesting that the testicular contribution of SP IGFBP-3 is probably minimal [27]. Seminal plasma of proteolyzed IGFBP-3 would lead to increased IGF bioavailability [38] because intact IGFBP-3 would bind strongly to IGFs. Hence, the proteolyzed IGFBP-3 fragments in SP might not have a direct effect compared to the intact IGFBP-3 on sperm motility because other IGF independent actions of IGFBP3 requires the intact molecule. The fact that no changes of IGFBP-3 levels in the SP of AZ, OZ and NZ men were observed in the present study suggests that proteolyzed IGFBP-3 did not exert any direct effects 
on sperm motility in vivo. Conversely, elevated PSA levels were observed in the SP of AZ men, but whether there is a direct relationship between elevated SP PSA levels and reduced sperm motility remains to be clarified.

Miao et al. [16] first investigated the direct effects of IGFs and IGFBPs on in vitro sperm motility by using the 'swim up' technique utilizing washed sperm technique combined with computer video tracking methods. These authors found that IGF-I and IGFBP-3 caused significant and differing changes in sperm motility parameters, whereas IGF-II, IGFBP-2 and IGF-I/IGFBP-3 had no significant effects [16]. The mechanisms by which the IGF-I and IGFBP-3 exert these in vivo and in vitro effects on mature sperm is difficult to explain because of the uniqueness of the mature spermatozoa in not having a normal functioning nucleus, nor many of the normal processes of RNA transcription and translation. Additionally, the presence of IGF-I and IGF-II mRNA in the male prostate gland and testis have been reported [42, 44], but little is known about their function in mature spermatozoa. In light of these findings, we sought to evaluate the expression of mRNAs for the IGFs and IGF receptors in mature motile human spermatozoa. We found that IGF-I mRNA was detectable in low amounts in mature motile spermatozoa from fertile volunteers, whereas IGF-II mRNA was highly expressed. Furthermore, we found that spermatozoa can express type I and type II IGF receptors. Animal studies in bovine species have shown an increase in motile sperm when exposed to exogenous recombinant IGF-I and IGF-II [45]. The effects of IGF-I on sperm motility suggest increased flagella motion and thrust that is important in facilitating penetration of the zona pellucida [46] and in the transport through oviductal mucus [47]. Early studies have shown that mRNA for IGF-I and IGF-I receptor are expressed in oviducts, uteri and embryos [48-50]. Bongso et al. [51, 52] reported a strong correlation of sperm motility with fertilization, and showed that in vitro fertilization rates were higher when female tubal cells were added to sperm and oocytes in a co-culture system. The demonstration of the presence of IGFs and their receptors imply that complex interactions between the oviductal IGFs, sperm cell IGF receptors and sperm micro-anatomical structures in the tail/flagellum (e.g., axoneme, microtubules, and tubulin) may be at play in the regulation of sperm motility.

Previous studies have reported an association between male infertility and future prostate cancer $[53,54]$. Dong et al. [55] also reported that IGF-II mRNA concentrations are 10-fold higher in prostate stromal cells from patients with BPH compared to normal men. Our findings that SP IGF-II increases with age suggest that the autocrine/paracrine actions of IGF-II may directly modulate prostate growth and possibly play a role in malignant prostatic changes. Our finding also helps to explain the paradox that although serum IGF-I has been shown to be a risk factor for prostate cancer, the incidence of BPH and prostate cancer increases whereas serum IGF-I levels decline with aging.

The limitations of our study are the small study numbers due to the rarity of $A Z$ and $O Z$ men in the general population and the fact that these men did not undergo specific examinations of the prostate and seminal vesicles by ultrasound or biochemical markers for improper function. The strengths, on the other hand, are the prospective design and the strict inclusion criteria of relatively healthy men over a wide age range with abnormalities of either sperm count or sperm motility, and no other ongoing medical 
conditions. Our data, thus, apply to men with stable causes, and not to those with transient dynamic causes of male infertility.

In summary, our study has demonstrated that changes in SP IGFs, IGFBPs and PSA profiles are associated with decreased sperm motility but not sperm count, and that the presence of IGF-I, IGF-II, IGF-I receptor and IGF-II receptor in mature motile spermatozoa suggests a role via direct effects on sperm motility. The mechanisms of how differences in SP IGF-I, IGF-II, IGFBP-2, and PSA levels between AZ and $\mathrm{OZ}$ men come about remains to be elucidated. Furthermore, our results also suggest a possible autocrine/paracrine role of prostatic IGF-II and the development of prostate diseases with male aging. Further studies are needed to better understand the clinical significance and biological functions of these SP peptides on sperm characteristics in male infertility and prostate diseases as men age.

\section{Declarations}

Funding information: LF, ANT and KOL are supported in part by a grant from the Endocrine and Metabolic Society of Singapore. ARH is supported in part by the VA Biomedical Merit Review (BX002905).

Declaration KCJY and ATB have nothing to declare.

Acknowledgements: The authors express their acknowledgment of the patients, control subjects, nurses, study coordinators, and sub-investigators involved in the study.

\section{References}

1. Abir R, Garor R, Felz C, Nitke S, Krissi H, et al. Growth hormone and its receptor in human ovaries from fetuses and adults. Fertil Steril 90, 1333-1339 (2008)

2. Hull KL, Harvey S. Growth hormone and reproduction: a review of endocrine and autocrine/paracrine interactions. Int J Endocrinol 2014, 234014 (2014)

3. Radicioni A, Paris E, Dondero F, Bonifacio V, Isidori A. Recombinant-growth hormone (rec-hGH) therapy in infertile men with idiopathic oligozoospermia. Acta Eur Fertil 25, 311-317 (1994)

4. Lee KO, Ng SC, Lee PS, Bongso AT, Taylor EA, et al. Effect of growth hormone therapy in men with severe idiopathic oligozoospermia. Eur J Endocrinol 132, 159-162 (1995)

5. Ovesen P, Jorgensen JO, Ingerslev J, Ho KK, Orskov H, et al. Growth hormone treatment of subfertile males. Fertil Steril 66, 292-298 (1996)

6. Breier BH, Vickers MH, Gravance CG, Casey PJ. Therapy with growth hormone: major prospects for the treatment of male subfertility? Endocr J 45 Suppl, S53-60 (1998)

7. Adamek A, Kasprzak A. Insulin-like growth factor (IGF) system in liver diseases. Int J Mol Sci 19, (2018)

8. Puche JE, Castilla-Cortazar I. Human conditions of insulin-like growth factor-I (IGF-I) deficiency. J Transl Med 10, 224 (2012) 
9. Glander HJ, Kratzsch J, Weisbrich C, Birkenmeier G. Insulin-like growth factor-I and alpha 2macroglobulin in seminal plasma correlate with semen quality. Hum Reprod 11, 2454-2460 (1996)

10. Rajaram S, Baylink DJ, Mohan S. Insulin-like growth factor-binding proteins in serum and other biological fluids: regulation and functions. Endocr Rev 18, 801-831 (1997)

11. Baxter RC. Circulating binding proteins for the insulinlike growth factors. Trends Endocrinol Metab 4, 91-96 (1993)

12. Gargosky SE, Pham HM, Wilson KF, Liu F, Giudice LC, et al. Measurement and characterization of insulin-like growth factor binding protein-3 in human biological fluids: discrepancies between radioimmunoassay and ligand blotting. Endocrinology 131, 3051-3060 (1992)

13. Ipsa E, Cruzat VF, Kagize JN, Yovich JL, Keane KN. Growth hormone and insulin-like growth factor action in reproductive tissues. Front Endocrinol (Lausanne) 10, 777 (2019)

14. Colombo JB, Naz RK. Modulation of insulin-like growth factor-1 in the seminal plasma of infertile men. J Androl 20, 118-125 (1999)

15. Lee HS, Park YS, Lee JS, Seo JT. Serum and seminal plasma insulin-like growth factor-1 in male infertility. Clin Exp Reprod Med 43, 97-101 (2016)

16. Miao ZR, Lin TK, Bongso TA, Zhou X, Cohen P, et al. Effect of insulin-like growth factors (IGFs) and IGF-binding proteins on in vitro sperm motility. Clin Endocrinol (Oxf) 49, 235-239 (1998)

17. Naderi G, Mohseni Rad H, Tabassomi F, Latif A. Seminal insulin-like growth factor-I may be involved in the pathophysiology of infertility among patients with clinical varicocele. Hum Fertil (Camb) 18, 92-95 (2015)

18. Ramasharma K, Cabrera CM, Li CH. Identification of insulin-like growth factor-II in human seminal and follicular fluids. Biochem Biophys Res Commun 140, 536-542 (1986)

19. Rosenfeld RG, Pham H, Oh Y, Lamson G, Giudice LC. Identification of insulin-like growth factorbinding protein-2 (IGF-BP-2) and a low molecular weight IGF-BP in human seminal plasma. J Clin Endocrinol Metab 70, 551-553 (1990)

20. Simopoulou M, Philippou A, Maziotis E, Sfakianoudis K, Nitsos N, et al. Association between male Infertility and seminal plasma levels of growth hormone and insulin-like growth factor-1. Andrologia 50, e13048 (2018)

21. Chokkalingam AP, Gao YT, Deng J, Stanczyk FZ, Sesterhenn IA, et al. Insulin-like growth factors and risk of benign prostatic hyperplasia. Prostate 52, 98-105 (2002)

22. Knuppel A, Fensom GK, Watts EL, Gunter MJ, Murphy N, et al. Circulating insulin-like growth factor-I concentrations and risk of 30 cancers: prospective analyses in UK Biobank. Cancer Res $\mathbf{8 0}, \mathbf{4 0 1 4 -}$ 4021 (2020)

23. Watts EL, Fensom GK, Smith Byrne K, Perez-Cornago A, Allen NE, et al. Circulating insulin-like growth factor-I, total and free testosterone concentrations and prostate cancer risk in 200000 men in UK Biobank. Int J Cancer 148, 2274-2288 (2021) 
24. Gomez JM, Maravall FJ, Gomez N, Navarro MA, Casamitjana R, et al. The IGF-I system component concentrations that decrease with ageing are lower in obesity in relationship to body mass index and body fat. Growth Horm IGF Res 14, 91-96 (2004)

25. Parsons JK, Bergstrom J, Silberstein J, Barrett-Connor E. Prevalence and characteristics of lower urinary tract symptoms in men aged > or $=80$ years. Urology 72, 318-321 (2008)

26. Rawla P. Epidemiology of prostate cancer. World J Oncol 10,63-89 (2019)

27. Lee KO, Oh Y, Giudice LC, Cohen P, Peehl DM, et al. Identification of insulin-like growth factor-binding protein-3 (IGFBP-3) fragments and IGFBP-5 proteolytic activity in human seminal plasma: a comparison of normal and vasectomized patients. J Clin Endocrinol Metab 79, 1367-1372 (1994)

28. Cooper TG, Noonan E, von Eckardstein S, Auger J, Baker HW, et al. World Health Organization reference values for human semen characteristics. Hum Reprod Update 16, 231-245 (2010)

29. Bongso A, Jarina AK, Ho J, Ng SC, Ratnam SS. Comparative evaluation of three sperm-washing methods to improve sperm concentration and motility in frozen-thawed oligozoospermic and normozoospermic samples. Arch Androl 31, 223-230 (1993)

30. Sanchez-Luengo S, Fernandez PJ, Romeu A. Insulin growth factors may be implicated in human sperm capacitation. Fertil Steril 83, 1064-1066 (2005)

31. Yilmaz A, Davis ME, Simmen RC. Reproductive performance of bulls divergently selected on the basis of blood serum insulin-like growth factor I concentration. J Anim Sci 77, 835-839 (1999)

32. Hoeflich A, Reichenbach HD, Schwartz J, Grupp T, Weber MM, et al. Insulin-like growth factors and IGF-binding proteins in bovine seminal plasma. Domest Anim Endocrinol 17, $39-51$ (1999)

33. Selvaraju S, Reddy IJ, Nandi S, Rao SB, Ravindra JP. Influence of IGF-I on buffalo (Bubalus bubalis) spermatozoa motility, membrane integrity, lipid peroxidation and fructose uptake in vitro. Anim Reprod Sci 113, 60-70 (2009)

34. Padilha RT, Magalhaes-Padilha DM, Cavalcante MM, Almeida AP, Haag KT, et al. Effect of insulin-like growth factor-I on some quality traits and fertility of cryopreserved ovine semen. Theriogenology $\mathbf{7 8}$, 907-913 (2012)

35. Kumar P, Suman, Pawaria S, Dalal J, Bhardwaj S, et al. Serum and seminal plasma IGF-1 associations with semen variables and effect of IGF-1 supplementation on semen freezing capacity in buffalo bulls. Anim Reprod Sci 204, 101-110 (2019)

36. Rodriguez-Martinez H, Martinez EA, Calvete JJ, Pena Vega FJ, Roca J. Seminal plasma: relevant for fertility? Int J Mol Sci 22, (2021)

37. Cohen P, Graves HC, PeehI DM, Kamarei M, Giudice LC, et al. Prostate-specific antigen (PSA) is an insulin-like growth factor binding protein-3 protease found in seminal plasma. J Clin Endocrinol Metab 75, 1046-1053 (1992)

38. Cohen P, Peehl DM, Graves HC, Rosenfeld RG. Biological effects of prostate specific antigen as an insulin-like growth factor binding protein-3 protease. J Endocrinol 142, 407-415 (1994) 
39. Ovesen P, Flyvbjerg A, Orskov H. Insulin-like growth factor I (IGF-I) and IGF binding proteins in seminal plasma before and after vasectomy in normal men. Fertil Steril 63, 913-918 (1995)

40. Henricks DM, Kouba AJ, Lackey BR, Boone WR, Gray SL. Identification of insulin-like growth factor I in bovine seminal plasma and its receptor on spermatozoa: influence on sperm motility. Biol Reprod 59, 330-337 (1998)

41. Mora Rodriguez JA, Porchia LM, Camargo F, Lopez-Bayghen E. The use of insulin-like growth factor 1 improved the parameters of the seminogram in a patient with severe oligoasthenoteratozoospermia. SAGE Open Med Case Rep 7, $2050313 X 19834154$ (2019)

42. Cohen P, PeehI DM, Lamson G, Rosenfeld RG. Insulin-like growth factors (IGFs), IGF receptors, and IGF-binding proteins in primary cultures of prostate epithelial cells. J Clin Endocrinol Metab 73, 401407 (1991)

43. Janssen J, Varewijck AJ, Brugts MP. The insulin-like growth factor-I receptor stimulating activity (IRSA) in health and disease. Growth Horm IGF Res 48-49, 16-28 (2019)

44. Zhou J, Bondy C. Anatomy of the insulin-like growth factor system in the human testis. Fertil Steril 60, 897-904 (1993)

45. Lackey BR, Boone WR, Gray SL, Henricks DM. Computer-assisted sperm motion analysis of bovine sperm treated with insulin-like growth factor I and II: implications as motility regulators and chemokinetic factors. Arch Androl 41, 115-125 (1998)

46. Katz DF, Drobnis EZ, Overstreet JW. Factors regulating mammalian sperm migration through the female reproductive tract and oocyte vestments. Gamete Res 22, 443-469 (1989)

47. Suarez SS, Dai XB, DeMott RP, Redfern K, Mirando MA. Movement characteristics of boar sperm obtained from the oviduct or hyperactivated in vitro. J Androl 13, 75-80 (1992)

48. Carlsson B, Hillensjo T, Nilsson A, Tornell J, Billig H. Expression of insulin-like growth factor-I (IGF-I) in the rat fallopian tube: possible autocrine and paracrine action of fallopian tube-derived IGF-I on the fallopian tube and on the preimplantation embryo. Endocrinology 133, 2031-2039 (1993)

49. Girbau M, Gonzalez-Guerrero PR, Bassas L, de Pablo F. Insulin receptors and insulin-like growth factor I receptors in embryos from gastrula until organogenesis. Mol Cell Endocrinol 90, 69-75 (1992)

50. Zhang X, Kidder GM, Watson AJ, Schultz GA, Armstrong DT. Possible roles of insulin and insulin-like growth factors in rat preimplantation development: investigation of gene expression by reverse transcription-polymerase chain reaction. J Reprod Fertil 100, 375-380 (1994)

51. Bongso A, Ng SC, Fong CY, Ratnam S. Improved fertilization rates of human oocytes in coculture. J In Vitro Fert Embryo Transf 8, 216-221 (1991)

52. Bongso TA, Ng SC, Mok H, Lim MN, Teo HL, et al. Effect of sperm motility on human in vitro fertilization. Arch Androl 22, 185-190 (1989)

53. Al-Jebari Y, Elenkov A, Wirestrand E, Schutz I, Giwercman A, et al. Risk of prostate cancer for men fathering through assisted reproduction: nationwide population based register study. BMJ 366, I5214 (2019) 
54. Eisenberg ML, Li S, Brooks JD, Cullen MR, Baker LC. Increased risk of cancer in infertile men: analysis of U.S. claims data. J Urol 193, 1596-1601 (2015)

55. Dong G, Rajah R, Vu T, Hoffman AR, Rosenfeld RG, et al. Decreased expression of Wilms' tumor gene WT-1 and elevated expression of insulin growth factor-II (IGF-II) and type 1 IGF receptor genes in prostatic stromal cells from patients with benign prostatic hyperplasia. J Clin Endocrinol Metab 82, 2198-2203 (1997)

\section{Tables}

Table 1 Oligonucleotide primers used for the reverse transcription polymerase chain reaction assay.

\begin{tabular}{|c|c|c|}
\hline Gene & Primer sequences & $\begin{array}{l}\text { Product length (base } \\
\text { pairs) }\end{array}$ \\
\hline IGF-I & $\begin{array}{l}\text { Sense 5'ACATCTCCCATCTCTCTGGATTTCCTTTTGC } \\
\text { Antisense } \\
\text { 5'CCCTCTACTTGCGTTCTTCAAATGTACTTCC }\end{array}$ & 514 \\
\hline IGF-II & $\begin{array}{l}\text { Sense 5'AGTCGATGCTGGTGCTTCTCACCTTCTTGGC } \\
\text { Antisense } \\
\text { 5'TGCGGCAGTTTTGCTCACTTCCGATTGCTGG }\end{array}$ & 538 \\
\hline $\begin{array}{l}\text { IGF-I } \\
\text { receptor }\end{array}$ & $\begin{array}{l}\text { Sense 5'AACCACGAGGCTGAGAAGCT } \\
\text { Antisense 5'CAGCATAATCACCAACCCTC }\end{array}$ & 447 \\
\hline $\begin{array}{l}\text { IGF-II } \\
\text { receptor }\end{array}$ & $\begin{array}{l}\text { Sense 5'TCAACATCTGTGGAAGTGTG } \\
\text { Antisense 5'GAATAGAGAAGTGTCCGGATCGGAGTC }\end{array}$ & 428 \\
\hline
\end{tabular}

Table 2 Baseline characteristics and semen parameters of fertile normozoospermic (NZ), and infertile asthenozoospermic (AZ) and oligozoospermic (OZ) men.

\begin{tabular}{|c|c|c|c|c|c|}
\hline \multirow{2}{*}{$\begin{array}{l}\text { Patient } \\
\text { groups }\end{array}$} & \multirow[t]{2}{*}{ N } & \multirow{2}{*}{$\begin{array}{l}\text { Age } \\
\text { (years) }\end{array}$} & \multirow{2}{*}{$\begin{array}{l}\text { Body mass index } \\
\left(\mathrm{kg} / \mathrm{m}^{2}\right)\end{array}$} & \multicolumn{2}{|c|}{ Semen parameters } \\
\hline & & & & $\begin{array}{l}\text { Sperm } \\
\text { count } \\
\left(\times 10^{6} / \mathrm{mL}\right)\end{array}$ & Sperm motility (\%) \\
\hline NZ & 20 & $35.2 \pm 5.3$ & $24.5 \pm 3.1$ & $45.0 \pm 4.9$ & $58.8 \pm 1.3$ \\
\hline$A Z$ & 18 & $37.1 \pm 8.1$ & $23.2 \pm 1.9$ & $57.9 \pm 8.7$ & $28.4 \pm 2.5^{\star}$ \\
\hline $\mathrm{OZ}$ & 10 & $33.0 \pm 5.9$ & $24.3 \pm 2.2$ & $7.5 \pm 1.8^{*}$ & $57.6 \pm 3.1$ \\
\hline
\end{tabular}

Data are presented as mean and standard deviation. 
*statistically significant compared with the other 2 groups $(P<0.0001$, ANOVA)

Table 3 Correlation analyses of seminal plasma IGFs, IGFBPs and PSA with sperm count, sperm motility and age.

\begin{tabular}{|llcl|}
\hline Seminal plasma & Sperm count & Sperm motility & Age \\
\hline IGF-I & & & \\
\hline IGF-II & $\mathbf{0 . 3 9 7 ^ { * }}$ & -0.194 & -0.013 \\
\hline IGFBP-2 & $\mathbf{0 . 5 5 2 ^ { \star \star }}$ & $\mathbf{- 0 . 4 7 5 ^ { \star \star }}$ & $\mathbf{0 . 3 0 5 * \star}$ \\
\hline IGFBP-3 & $\mathbf{0 . 0 3 2 ^ { \star \star * }}$ & $\mathbf{- 0 . 3 0 2 ^ { \star \star * }}$ & 0.284 \\
\hline PSA & 0.053 & 0.052 & 0.113 \\
\hline
\end{tabular}

${ }^{\star} P<0.01 ; * \star P<0.001$ and ${ }^{* * *} P<0.05$.

\section{Figures}
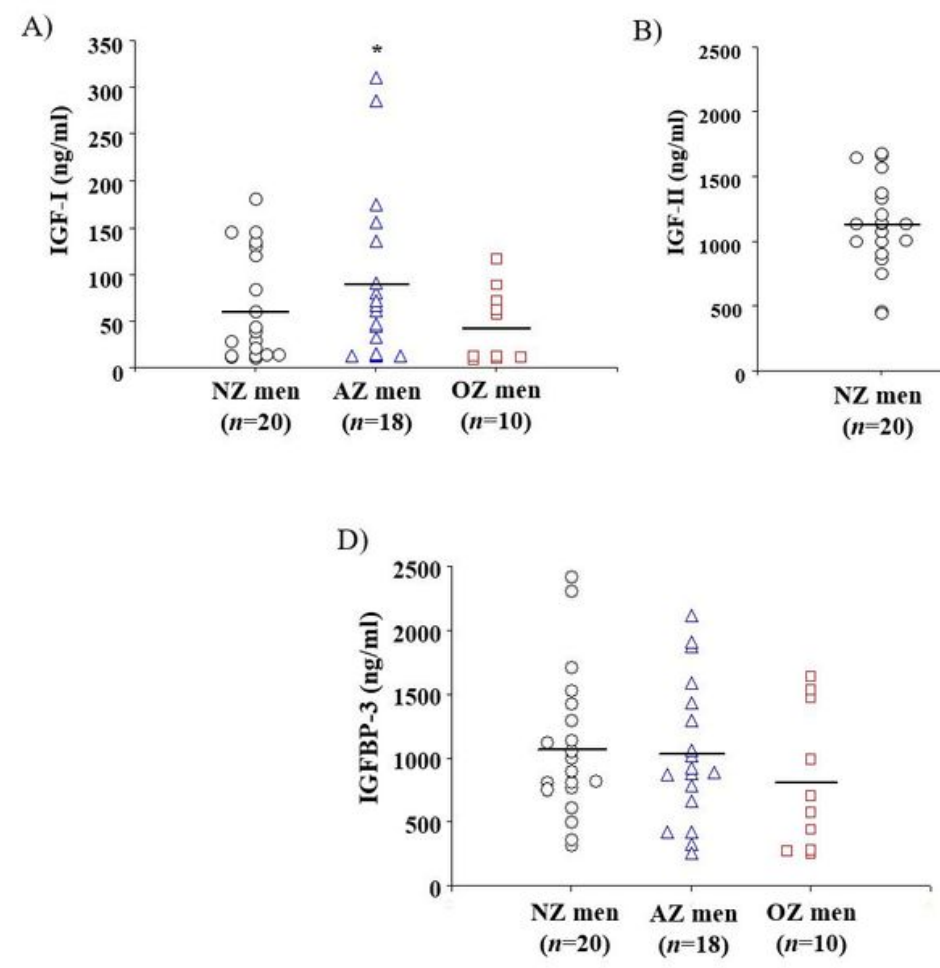
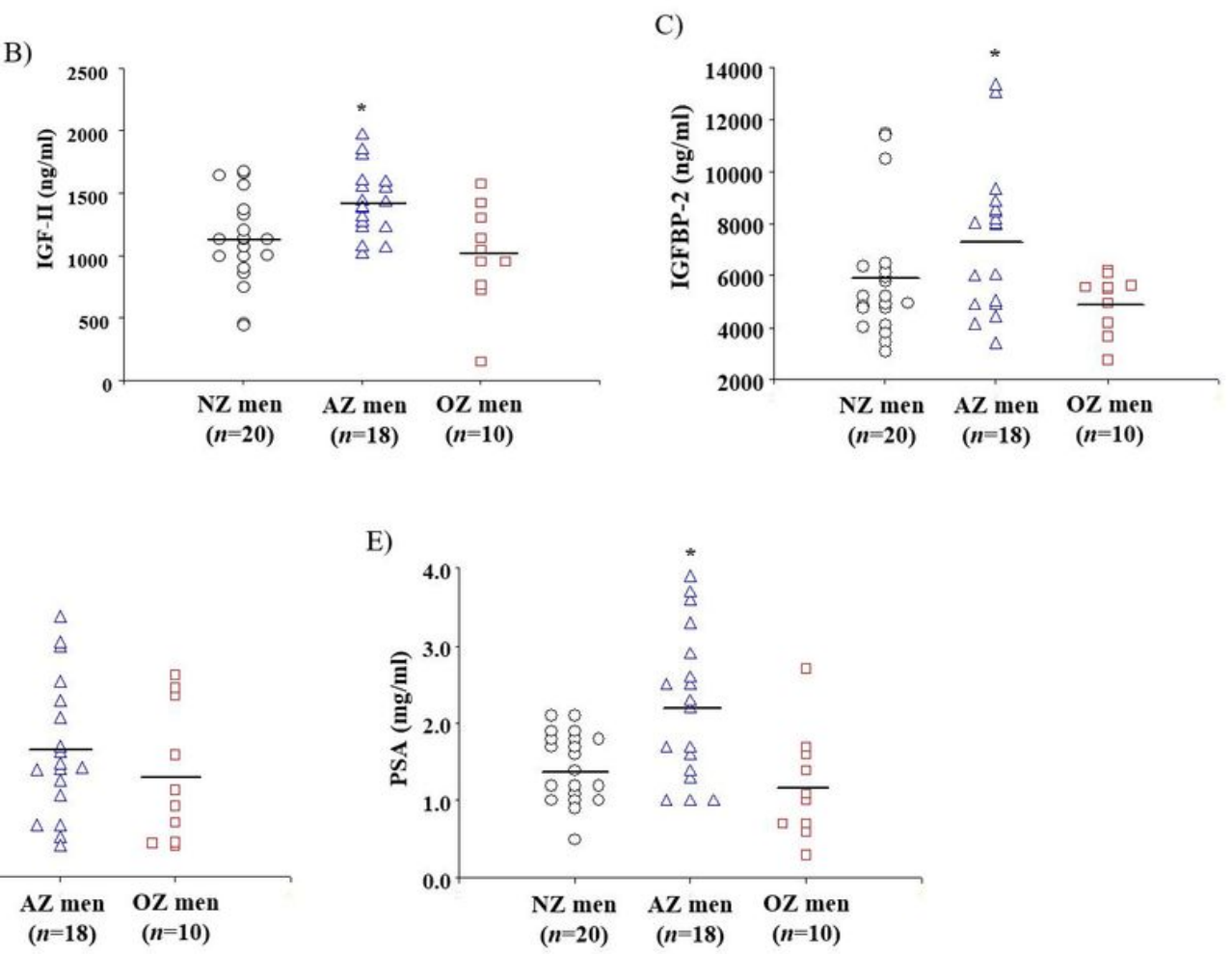

Figure 1 
Seminal plasma (A) IGF-I, (B) IGF-II, (C) IGFBP-2, (D) IGFBP-3 and (E) PSA levels of fertile normozoospermic (NZ), and infertile asthenozoospermic (AZ) and oligozoospermic (OZ) men. The horizontal line indicates the mean value and * indicates statistical significance $(P<0.05$, ANOVA).

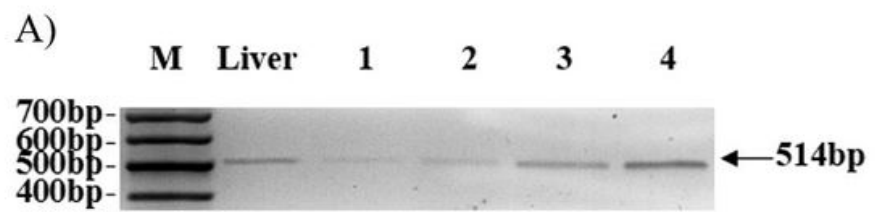

IGF-I

C)

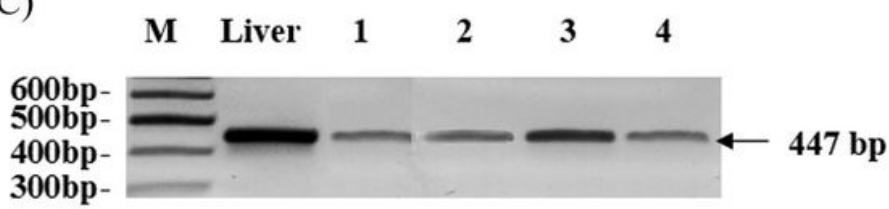

IGF-IR
B)

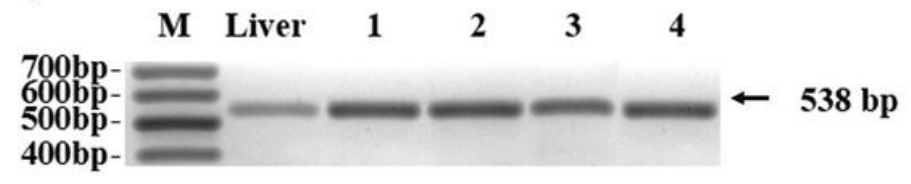

IGF-II

D)

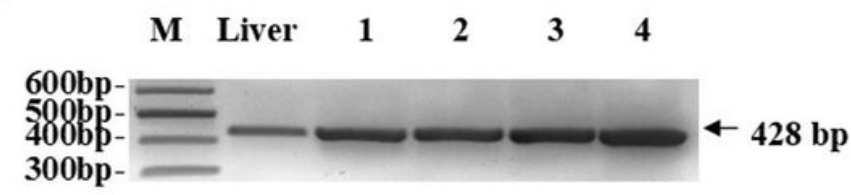

IGF-IIR

Figure 2

Agarose gel (1.5\%) electrophoresis of RT-PCR products of (A) IGF-I, (B) IGF-II, (C) IGF-I receptor (IGF-IR) and (D) IGF-II receptor (IGF-IIR) from different sperm samples (Lane 1-4). A band corresponding to the RTPCR products of (A) IGF-I (514 base pairs), (B) IGF-II (538 base pairs), (C) IGF-IR (447 base pairs) and (D) IGF-IIR (428 base pairs) are shown in each lane. Hepatic mRNA was used as a positive control. Lane M represents the molecular markers (100-base pair ladder). 